\title{
Sistem Pakar Mendeteksi Kerusakan Sistem Hydrolic Pada Excavator Dengan Metode Certainty Factor
}

\author{
Bryan Pratama Sembiring ${ }^{1 *}$, Hasanul Fahmi \\ ${ }^{1,2}$ STMIK Pelita Nusantara \\ Jl. Iskandar Muda No. 1 Medan 20154 \\ Corresponding e-mail : bryansembiring9@gmail.com
}

\begin{abstract}
Abstrak - Alat berat excavator biasa digunakan dalam industri konstruksi, pertanian atau perhutanan. Sistem hidrolik merupakan sistem penerusan daya dengan menggunakan fluida cair. Seorang pakar harus mampu menyusun kembali pengetahuan-pengetahuan yang diperoleh, dapat memecahkan aturan-aturan serta menentukan relevansi kepakarannya. Metode Certainty Factor ini bisa mengolah 2 bobot dalam sekali perhitungan tidak ada aturan untuk mengkombinasikan bobotnya, karena untuk kombinasi seperti apapun hasilnya akan tetap sama. Untuk mendapatkan tingkat keyakinan dapat dengan cara mewawancarai seorang pakar dengan aturan $C F$ (Rule). Aplikasi sistem pakar komersial berbasis rule (rule-based systems), yaitu pengetahuan sebagai prosedur-prosedur pemecahan masalah. CF gabungan merupakan Certainty Factor akhir dari sebuah calon konklusi. CF ini dipengaruhi oleh semua CF pararel dari aturan yang menghasilkan konklusi. Dalam penelitian ini Data Kerusakan diberi Kode (C01, C02, C03, C04, C05) dan nama kerusakan (Winding Imposible, Lowering, Imposible, Free Drop Imposible, Hunting Occurs, Neutral Maintenance Possible). Hasil perhitungan pada studi kasus menggunakan metode $\mathrm{CF}$, bahwa sistem hydrolic mengalami Winding Imposible dengan Nilai CF 0,9916 selanjutnya sistem CF diagnosa kerusakan akan memberikan solusi sesuai kode kerusakan.
\end{abstract}

Kata Kunci: Data Gabungan, Kerusakan, Certainty Faktor, Sistem Pakar

\section{Pendahuluan}

Pada saat ini perusahaan kontraktor swasta dibidang maintenance dan produk support memiliki intensitas produksi yang sangat tinggi, dengan tingginya mobilitas excavator tentu diperlukan maintenance secara rutin dan tepat untuk mendeteksi kerusakan hydrolic pada excavator. Terdapat lima faktor yang mempengaruhi kerusakan mesin hydrolic excavator yaitu Winding Imposible, Lowering Imposible, Free Drop Imposible, Hunting Occurs, dan Neutral Maintenance Possible, dalam mendiagnosa ke lima faktor kerusakan mesin tersebut, setiap mekanik harus membuka shop manual kemudian menelusuri satu per satu permasalahan sehingga diperoleh suatu kesimpulan. Hal ini menyebabkan beberapa permasalahan yaitu adanya hasil diagnosa kerusakan yang berbeda oleh mekanik dan waktu yang dibutuhkan cukup lama pada proses pemeriksaan, sehingga dibutuhkan sebuah sistem untuk mempercepat proses diagnosa kerusakan hydrolic pada mesin excavator yaitu sistem pakar [1].

Excavator adalah alat berat yang biasa digunakan dalam industri konstruksi, pertanian atau perhutanan.Mempunyai belalai yang terdiri dari dua piston yang terdekat dengan body disebut boom dan yang mempunyai bucket (ember keruk) disebut dipper. Ruang pengemudi disebut House, terletak diatas roda (trackshoe), dan bisa berputar arah 360 derajat. Excavators ada yang mempunyai roda dari ban biasa digunakan untuk jalanan padat dan rata disebut "Wheel Excavators" dan ada yang mempunyai roda dari rantai besi yang akan memudahkannya untuk berjalan di jalanan yang tidak padat atau mendaki. Excavators beroda rantai besi ini disebut juga "Crawler Excavators" Tungkai dari excavators dioperasikan dengan sistem engsel (winches) yang ditarik oleh mesin hydraulic dengan menggunakan kawat baja. Excavators memiliki fungsi utama untuk menggali dan memuat tanah galian tersebut kedalam truck atau lokasi penumpukan [2]. Dalam industri perhutanan Excavators digunakan untuk mengangkut kayu (logs).

Metode certainty factor menyatakan kepercayaan dalam sebuah kejadian atau fakta berdasarakan bukti atau penilaian pakar. Certainty factor menggunakan suatu nilai untuk mengasumsi derajat keyakinan seorang pakar terhadap suatu data, sehingga, berdasarkan fakta-fakta gejala kerusakan yang ada dimasukkan ke dalam sistem pakar maka akan didapat kemungkinan dari jenis kerusakan yang terjadi [3]. Sistem pakar adalah sistem cerdas berbasis komputer digunakan dalam penyelesaian masalah yang hanya bisa dilakukan oleh ahli/pakar pada suatu bidang[14]. Sistem pakar dapat membantu aktivitas para pakar sebagai asisten yang berpengalaman dan mempunyai pengetahuan yang dibutuhkan. Dalam penyusunannya, sistem pakar mengkombinasikan kaidah-kaidah penarikan kesimpulan (inference rules) dengan basis pengetahuan tertentu yang diberikan oleh satu atau 
lebih pakar dalam bidang tertentu. Kombinasi dari kedua hal tersebut disimpan dalam komputer, yang selanjutnya digunakan dalam proses pengambilan keputusan untuk penyelesaian masalah tertentu [4]. Sistem pakar telah digunakan dalam masa sekarang ini pada berbagai aplikasi, seperti konfigurasi, diagnosis, instruksi, interpretasi, monitoring, perencanaan, peramalan, pengendalian dan perbaikan (Agustyan dan Gumilang, 2015). Komponen-komponen dasar membangun sistem adalah sebagai antar muka (user interface), basis pengetahuan (knowledge base) dan mesin inferensi (inference engine). Permasalahan pada perusahaan diharapkan dapat terselesaikan melalui sistem pakar [5]. Sistem pakar diterapkan untuk mendukung aktivitas pemecahan masalah. Tujuan dari penelitian ini adalah penerapan sistem pakar untuk mendiagnosa kerusakan sistem hydrolic pada excavator, dengan menggunakan metode certainty factor.

\section{Tinjauan Pustaka}

\subsection{Pengertian Sistem Pakar}

Seseorang yang memiliki pengetahuan tertentu dan mampu menjelaskan suatu tanggapan, mempelajari hal-hal baru seputar topik permasalahan, menyusun kembali pengetahuanpengetahuan yang didapatkan dan dapat memilah aturan serta menentukan relevan kepakarannya disebut sebagai seorang pakar. Sistem pakar adalah suatu program komputer cerdas yang menggunakan pengetahuan (knowledge) dan prosedur inferensi untuk menyelesaikan masalah yang cukup sulit sehingga membutuhkan seorang yang ahli untuk menyelesaikannya [6]. Pengantar Sistem Pakar dan Metode). Kecerdasan buatan atau Artificial Intellenge (AI) dapat didefinisikan sebagai sub bidang pengetahuan komputer yang khusus ditujukan untuk membuat software dan hardware yang sepenuhnya biasa menirukan beberapa fungsi otak manusia [7].

\subsection{Certainy Factor}

Faktor kepastian (Certainty Factor) menyatakan kepercayaan dalam sebuah kejadian (atau fakta atau hipotesis) berdasarkan bukti atau penilaian pakar. CF menggunakan suatu nilai untuk asumsi derajat keyakinan seorang pakar terhadap suatu data [8]. Langkah-langkah perhitungan metode certainty factor untuk membangun sistem pakar, penentuan data kerusakan yang sistem hydrolic, Penentuan data gejala. Penentuan data gabungan, antara data gejala dengan data kerusakan sistem hydrolic. Penentuan nilai MB, MD dilanjutkan dengan penentuan nilai CF. Pemilihan data gejalan oleh user. Perhitungan nilai CF dari gejala user [9]. Hasil diagnosa kerusakan sistem hydrolic [10]. Rumus dasar
$C F: C F(h, e)=M B(h, e)-M D(h, e)$

Keterangan:

$\mathrm{CF}(\mathrm{h}, \mathrm{e})=$ Certainty Factor (faktor kepastian) dalam hipotesis ; h dipengaruhi oleh evidence (gejala) e. $\mathrm{MB}(\mathrm{h}, \mathrm{e})=$ Measure of Belief (tingkat keyakinan), merupakan ukuran kepercayaan dari hipotesis $h$ dipengaruhi oleh evidence (gejala) e.

$\mathrm{MD}(\mathrm{h}, \mathrm{e})=$ Measure of Disbelief (tingkat ketidakyakinan), merupakan ukuran ketidakpercayaan dari hipotesis $\mathrm{h}$ dipengaruhi oleh gejala $\mathrm{e} ; \mathrm{h}=$ Hipotesa atau konklusi yang dihasilkan (antara 0 dan 1$)$. e = Evidence atau peristiwa atau fakta (gejala). Perhitungan selanjutnya adalah kombinasi dua atau lebih rule dengan evidence berbeda tetapi dalam hipotesis yang sama [11]:

Rule $1 \mathrm{CF}(h, e 1)=C F 1=C(e 1) x C F($ Rule 1$) \ldots \ldots . .(2)$

Rule $2 \mathrm{CF}(h, e 2)=C F 2=C(e 2) x C F($ Rule2 $) \ldots . . . .(3)$

CFkomb. $[C F 1, C F 2]=C F 1+C F 2(1-C F 1) \ldots \ldots . .(4)$

Certainty factor adalah suatu metode untuk membuktikan apakah suatu fakta itu pasti ataukah tidak pasti yang berbentuk metric yang biasanya digunakan dalam sistem pakar. Metode ini sangat cocok untuk sistem pakar yang mendiagnosis sesuatu yang belum pasti. Metode certainty factor ini bisa mengolah 2 bobot dalam sekali perhitungan. Untuk bobot yang lebih dari 2 banyaknya, untuk melakukan perhitungan tidak terjadi masalah apabila bobot yang dihitung teracak, artinya tidak ada aturan untuk mengkombinasikan bobotnya, karena untuk kombinasi seperti apapun hasilnya akan tetap sama. Perhitungan certainty factor [12] :

Rule 1: IF batuk THEN penyakit = batuk rejan $(\mathrm{CF}$ $=0,8) ;$ Rule 2 : IF demam THEN penyakit $=$ batuk rejan $(\mathrm{CF}=0,6)$

$\mathrm{CF} 1=\mathrm{C}($ batuk $) \times \mathrm{CF}($ Rule 1$)=1 \times 0,8=0,8 ; \mathrm{CF} 2$ $=\mathrm{C}($ demam $) \times \mathrm{CF}($ Rule 2$)=1 \times 0,6=0,6 ; \mathrm{CF}=$ $\mathrm{CF} 1+\mathrm{CF} 2(1-\mathrm{CF} 1)=0,8+0,6(1-0,8)=0,92$

Untuk mendapatkan tingkat keyakinan dapat dengan cara mewawancarai seorang pakar dengan aturan $\mathrm{CF}$ (Rule). Sedangkan untuk menentukan nilai tingkat keyakinan dari user juga dapat menggunakan aturan yang sama. Nilai $\mathrm{CF}($ Rule) dapat di interpretasi dengan "term" dari pakar, yang diubah menjadi nilai tertentu sesuai table berikut : Tabel 1 . 
Tabel 1. Certainty Factor Rule

\begin{tabular}{|l|c|}
\hline \multicolumn{1}{|c|}{ Uncertainty Term } & Certainty factor \\
\hline Pasti Tidak & -1.0 \\
\hline Hampir Pasti Tidak & -0.8 \\
\hline Kemungkinan Besar Tidak & -0.6 \\
\hline Mungkin Tidak & -0.4 \\
\hline Tidak Tahu & -0.2 sampai 0.2 \\
\hline Mungkin & 0.4 \\
\hline Kemungkinan Besar & 0.6 \\
\hline Hampir Pasti & 0.8 \\
\hline Pasti & 1.0 \\
\hline
\end{tabular}

Contoh : Jika gejalanya pendarahan maka hampir pasti penyakit yang di derita adalah cervicitis.. Rule : IF (pendarahan) then penyakit $=$ cervicitis. $(\mathrm{CF}=$ 0.8). Cara lain untuk mendapatkan tingkat keyakinan adalah dengan metode Net belief, yaitu Perhitungan Net Belief. $()=,\max [(\mid),()]-() \max [1,0]-()$ $()=,\min [(\mid),()]-() \min [1,0]-() \mathrm{CF}[\mathrm{H}, \mathrm{E}]=$ $\mathrm{MB}[\mathrm{H}, \mathrm{E}]-\mathrm{MD}[\mathrm{H}, \mathrm{E}]$.
Keterangan : $\mathrm{MB}[\mathrm{h}, \mathrm{e}]=$ Mesure of Belief (tingkat keyakinan), merupakan ukuran kenaikan dari kepercayaan hipotesis $\mathrm{H}$ dipengaruhi oleh fakta $\mathrm{E}$. $\mathrm{MD}[\mathrm{h}, \mathrm{e}]=$ Mesure of Belief (tingkat ketidakyakinan), merupakan ukuran kenaikan dari kepercayaan hipotesis $\mathrm{H}$ dipengaruhi oleh fakta $\mathrm{E}$. $\mathrm{P}(\mathrm{H})=$ probabilitas gejala $\mathrm{P}(\mathrm{H} \mid \mathrm{E})=$ probabilitas gejala pada penyakit.

\section{Metode Penelitian}

Untuk membantu dalam penyusunan penelitian ini, maka perlu adanya susunan kerangka kerja (frame work) yang jelas tahapan-tahapannya. Kerangka kerja ini merupakan langkah-langkah yang akan dilakukan dalam penyelesaian masalah yang akan dibahas.Tahapan awal dalam perancangan dan pengembangan sistem adalah menentukan kebutuhan-kebutuhan sistem pakar diagnosis kerusakan sistem hydrolic yang dibangun, Gambar 1.

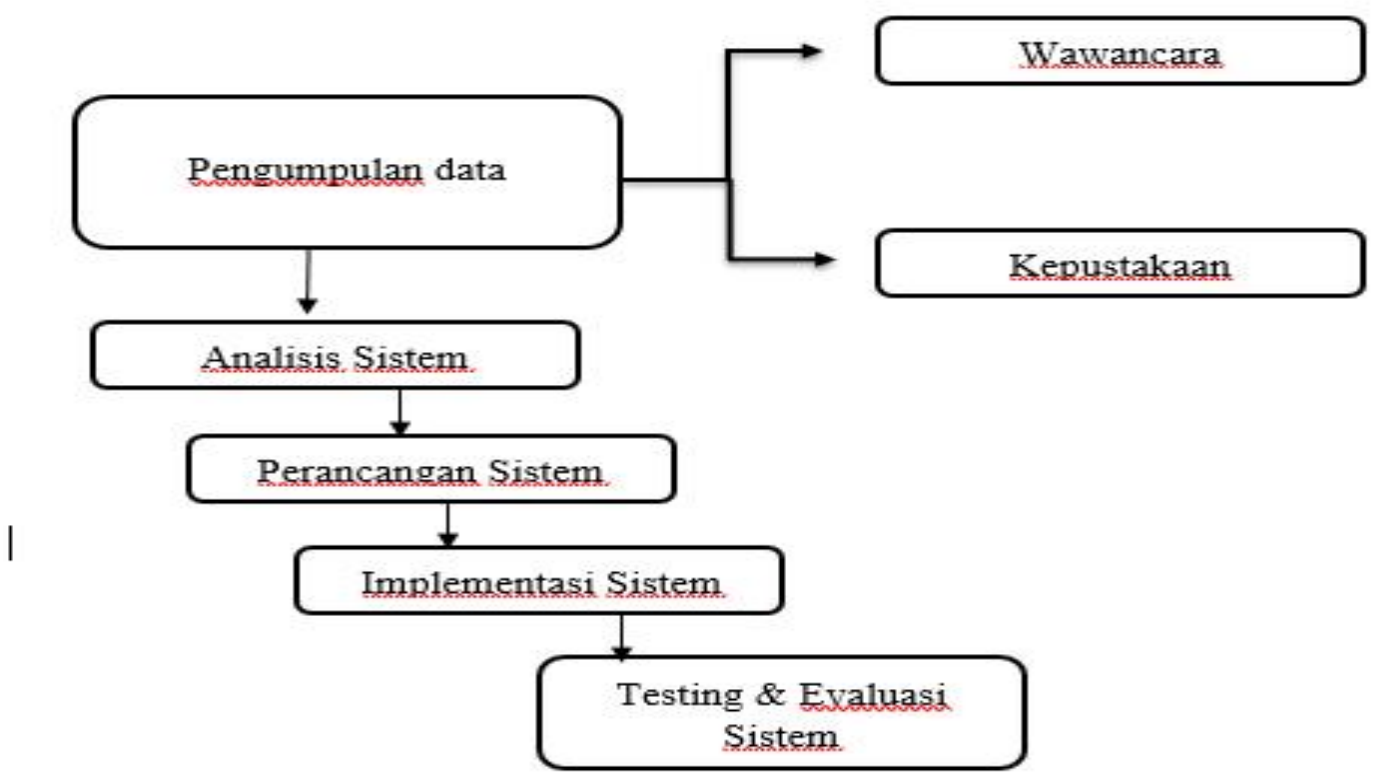

Gambar 1. Metodologi Penelitian

Penentuan data gabungan, merupakan data gabungan antara data gejala dengan data kerusakan sistem hydrolic [10]. Penentuan nilai MB MD dilanjutkan dengan penentuan nilai CF. Pemilihan data gejala oleh user. Perhitungan nilai $\mathrm{CF}$ dari gejala user. Hasil diagnosa kerusakan sistem hydrolic. Hasil diagnosis sistem pakar berupa persentase kerusakan. Persentase kerusakan yang dipakai untuk hasil diagnosis adalah persentase terbesar.

Tahapan desain sistem yang akan dibangun menggunakan Unified Modeling Language (UML) yang mendukung konsep pemodelan programming berbasis Object Oriented Programming (OOP) seperti yang akan diterapkan pada tahap penulisan kode program. Penulisan kode program (coding) menggunakan bahasa pemograman Visual Studio 2010. Manajemen basis data yang digunakan adalah Microsoft Access 2010.

\section{Hasil dan Pembahasan}

Analisis sistem yang dibangun untuk mengidentifikasi kerusakan sistem hydrolic pada excavator dengan menggunakan metode $\mathrm{CF}$ ini berupa data gejala dari setiap jenis kerusakan beserta nilai kepastian $\mathrm{MB}$ dan nilai MD yang telah 
diberikan oleh seorang pakar. Pada penelitian ini digunakan pengambilan data kerusakan terhadap 5 bagian utama excavator. Berikut contoh data pada bagian winch body. Adapun data tesebut nantinya diproses menghasilkan kesimpulan jenis kerusakan sistem hydrolic pada excavator berdasarkan Gejala yang akan dipilih User.

a. Jenis Kerusakan

Tabel 2. Jenis-Jenis Kerusakan Sistem Hydrolic Excavator

\begin{tabular}{|l|l|l|}
\hline No. & Kode Keruskaan & \multicolumn{1}{c|}{ Nama Kerusakan } \\
\hline 1 & C01 & Winding Imposible \\
\hline 2 & C02 & Lowering Imposible \\
\hline 3 & C03 & Free Drop Imposible \\
\hline 4 & C04 & Hunting Occurs \\
\hline 5 & C05 & Neutral Maintenance Possible \\
\hline
\end{tabular}

b. Jenis Gejala

Tabel 3. Jenis-Jenis Gejala Kerusakan Sistem Hydrolic Excavator

\begin{tabular}{|l|c|l|}
\hline No. & Kode & \multicolumn{1}{|c|}{ Gejala Kerusakan } \\
\hline 1 & ACG01 & Brake Drum is Not Released \\
\hline 2 & ACG02 & Hydraulic Pressure is Low \\
\hline 3 & ACG03 & Clutch does not Function Normally \\
\hline 4 & ACG04 & $\begin{array}{l}\text { Winch Motor does not Function } \\
\text { Normally }\end{array}$ \\
\hline 5 & ACG05 & Clutch Pressure is Low \\
\hline 6 & ACG06 & Clutch Slips \\
\hline 7 & ACG07 & Hydraulic Oil Feed Pressure is Low \\
\hline 8 & ACG08 & $\begin{array}{l}\text { Counter Balance Valve does not } \\
\text { Function Normally }\end{array}$ \\
\hline 9 & ACG09 & Clutch is not Released \\
\hline 10 & ACG10 & Air is Mixed into Winch Circuit \\
\hline 11 & ACG11 & Air is Mixed into Counterbalance Valve \\
\hline 12 & ACG12 & Brake Lining is Seriously Worn Out \\
\hline 13 & ACG13 & Oil Attaches \\
\hline 14 & ACG14 & Motor Drain \\
\hline
\end{tabular}
penggabungan kepercayaan dan ketidak kepercayaan dalam bilangan yang tunggal Certainty Factor menggunakan suatu nilai untuk mengasumsikan derajat keyakinan seorang pakar terhadap suatu data. Dalam pengolahan data dan pengambilan keputusan, metode Certainty Factor memiliki sebuah aturan JIKA E MAKA $\mathrm{H}$ adalah sebagai berikut : $\mathrm{CF}$ [H.E] $=\mathrm{MB}[\mathrm{H}, \mathrm{E}]-\mathrm{MD}[\mathrm{H}, \mathrm{E}]$

$\mathrm{CF}=$ Certainty Factor hipotesa dalam hipotesis $\mathrm{H}$ yang dipengaruhi oleh fakta $\mathrm{E} ; \mathrm{MB}=$ meansure of believe, nilai kenaikan dari kepercayaan hipotesis $\mathrm{H}$ dipengaruhi oleh fakta $\mathrm{E}$. $\mathrm{MD}=$ meansure of disbelieve, nilai kenaikan dari ketidakpercayaan hipotesis $\mathrm{H}$ dipengaruhi oleh fakta $\mathrm{E}$. $\mathrm{H}=$ Hipotesis (dugaan). $\mathrm{E}=$ Evidence (Peristiwa/fakta).

Certainty Factor memiliki sebuah aturan JIKA E MAKA $\mathrm{H}$ adalah sebagai berikut:

Cfcombine $\mathrm{CF}[\mathrm{H}, \mathrm{E}] 1,2=\mathrm{CF}[\mathrm{H}, \mathrm{E}] 1+$

$\mathrm{CF}[\mathrm{H}, \mathrm{E}] 2 *[1-\mathrm{CF}[\mathrm{H}, \mathrm{E}] 1]$

$\mathrm{CF}$ combineCF[H,E]old3=CF[H,E]old $+\mathrm{CF}[\mathrm{H}, \mathrm{E}] 3 *[1$

$-\mathrm{CF}[\mathrm{H}, \mathrm{E}] \mathrm{old}]$.

Kaidah Produksi Penentuan Kerusakan Sistem Hydrolic biasanya dituliskan dalam bentuk jikamaka (IFTHEN). Kaidah ini dapat dikatakan sebagai hubungan impliksi dua bagian, yaitu bagian premise (jika) dan bagian konklusi (maka). Adapun basis aturan disajikan dalam aturan-aturan yang berbentuk pasangan keadaan aksi (condition-action) "JIKA (IF) keadaan terpenuhi atau terjadi MAKA (THEN):

Rule 1: IF Brake Drum is Not Released is True $A N D$ Hydraulic Pressure is Low is True $A N D$ Clutch does not Function Normally is True

$A N D$ Winch Motor does not Function Normally is True

AND Clutch Pressure is Low is True

THEN Winding Imposible

Rule 2: IF Clutch Slips is True Lowis True

AND Hydraulic Oil Feed Pressure is

AND Counter Balance Valve does not Function Normally is True

AND Clutch is not Released is True

AND Air is Mixed into Winch Circuit is True

THEN Lowering Imposible

Rule 3: IF Air is Mixed into Counterbalance Valve is True

OutTrue

AND Brake Lining is Seriously Worn

AND Oil Attaches is True

AND Motor Drain is True

THEN Free Drop Imposible

Sedangkan untuk setiap gejala kerusakan, diberi bobot, Tabel 4. 
Tabel 4. Bobot Gejala Kerusakan

\begin{tabular}{|c|c|c|c|c|c|}
\hline Kode & $\begin{array}{c}\text { Jenis } \\
\text { Kerusakan }\end{array}$ & Gejala Kerusakan & MB & MD & Gejala Kerusakan \\
\hline ACG01 & \multirow{5}{*}{$\begin{array}{l}\text { Winding } \\
\text { Imposible }\end{array}$} & Brake Drum is Not Released & 0.8 & 0.09 & \multirow{5}{*}{ 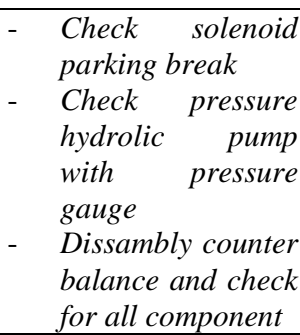 } \\
\hline ACG02 & & Hydraulic Pressure is Low & 0.7 & 0.09 & \\
\hline ACG03 & & Clutch does not Function Normally & 0.5 & 0.04 & \\
\hline ACG04 & & Winch Motor does not Function Normally & 0.4 & 0.03 & \\
\hline ACG05 & & Clutch Pressure is Low & 0.4 & 0.0 .4 & \\
\hline ACG01 & \multirow[b]{5}{*}{$\begin{array}{l}\text { Lowering } \\
\text { Imposible }\end{array}$} & Brake Drum is Not Released & 0.4 & 0.01 & \multirow{5}{*}{$\begin{array}{l}\text { Check spoll } \\
\text { control value and } \\
\text { cleaning spoll } \\
\text { control value with } \\
\text { contact cleaner } \\
\text { Replace with new } \\
\text { part motor drain } \\
\text { - Check all syetem } \\
\text { break hydrolic } \\
\text { Test drain } \\
\text { hydrolic with tools } \\
\text { tetra gauge }\end{array}$} \\
\hline ACG06 & & Clutch Slips & 0.3 & 0.02 & \\
\hline ACG04 & & Winch Motor does not Function Normally & 0.7 & 0.02 & \\
\hline ACG08 & & Counter Balance Valve does not Function Normally & 0.8 & 0.02 & \\
\hline ACG10 & & Air is Mixed into Winch Circuit & 0.7 & 0.06 & \\
\hline ACG02 & \multirow{5}{*}{$\begin{array}{l}\text { Free Drop } \\
\text { Imposible }\end{array}$} & Hydraulic Pressure is Low & 0.2 & 0.03 & \multirow{5}{*}{$\begin{array}{l}\text { - Check proposional } \\
\text { value(prv) in } \\
\text { hydrolic pump } \\
\text { - Check with tool } \\
\text { DMM (digital } \\
\text { multy tester) or } \\
\text { replaced solenoid } \\
\text { pro with new part } \\
\text { - Shop manual }\end{array}$} \\
\hline ACG05 & & Clutch Pressure is Low & 0.6 & 0.01 & \\
\hline ACG07 & & Hydraulic Oil Feed Pressure is Low & 0.8 & 0.00 & \\
\hline ACG09 & & Clutch is not Released & 0.9 & 0.02 & \\
\hline ACG12 & & Brake Lining is Seriously Worn Out & 0.6 & 0.02 & \\
\hline ACG04 & \multirow[b]{5}{*}{$\begin{array}{c}\text { Hunting } \\
\text { Occurs }\end{array}$} & Hydraulic Pressure is Low & 0.1 & 0.02 & \multirow{5}{*}{$\begin{array}{lr}\text { Change } & \text { oil } \\
\text { hydrolic with new } & \text { nil hydrolic, } \\
\text { oil } & \text { replace filter } \\
\text { hydrolic with new } & \text { oart } \\
\text { ort or } \\
\text { mainteinaince } \\
\text { from unit whit } \\
\text { spec shop manual } \\
\text { Check solenoid } \\
\text { parking break }\end{array}$} \\
\hline ACG09 & & Clutch Pressure is Low & 0.5 & 0.01 & \\
\hline ACG11 & & Air is Mixed into Counterbalance Valve & 0.7 & 0.02 & \\
\hline ACG13 & & Oil Attaches & 0.8 & 0.03 & \\
\hline ACG14 & & Motor Drain & 0.7 & 0.03 & \\
\hline ACG09 & \multirow{5}{*}{$\begin{array}{l}\text { Neutral } \\
\text { Maintenance } \\
\text { Possible }\end{array}$} & Clutch Pressure is Low & 0.3 & 0.03 & \multirow{5}{*}{$\begin{array}{l}\text { - Check with tool } \\
\text { DMM (digital } \\
\text { multy tester) or } \\
\text { replaced solenoid } \\
\text { pro with new part } \\
\text { Test drain } \\
\text { hydrolic with tools } \\
\text { tetra gauge }\end{array}$} \\
\hline ACG13 & & Oil Attaches & 0.6 & 0.02 & \\
\hline ACG10 & & Air is Mixed into Winch Circuit & 0.9 & 0.01 & \\
\hline ACG11 & & Hydraulic Oil Feed Pressure is Low & 0.9 & 0.03 & \\
\hline ACG14 & & Motor Drain & 0.6 & 0.02 & \\
\hline
\end{tabular}

Certainty Factor digunakan untuk memberikan tingkat keyakinan terhadap hasil perhitungan, 
karena seorang pakar sering menganalisis informasi yang ada dengan memberikan faktor ketidakpastian, begitu pula terjadi dengan sebuah sistem pakar. Dalam sistem ini untuk mendapatkan faktor kepastian, setiap jawaban dari pengguna akan memiliki bobotnya masing-masing.

Table 5. Bobot Nilai MB Table 6. Bobot Nilai MD

\begin{tabular}{|l|l|}
\hline Keterangan & $\begin{array}{l}\text { Nilai } \\
\text { MB }\end{array}$ \\
\hline Tidak & \multicolumn{1}{|c|}{0} \\
\hline Sedikit Yakin & $0.40-$ \\
& 0.74 \\
\hline Cukup yakin & $0.75-$ \\
& 0.89 \\
\hline Yakin & $0.90-$ \\
& 0.99 \\
\hline Sangat yakin & 1.0 \\
\hline
\end{tabular}

\begin{tabular}{|l|l|}
\hline Keterangan & $\begin{array}{l}\text { Nilai } \\
\text { MD }\end{array}$ \\
\hline Tidak Yakin & $0-0.02$ \\
\hline Sedikit Yakin & $\begin{array}{l}0.03- \\
0.05\end{array}$ \\
\hline Yakin & $0.06-$ \\
& 0.08 \\
\hline Sangat Yakin & $0.09-$ \\
& 0.10 \\
\hline
\end{tabular}

Contoh kasus perhitungan Certainty Factor secara manual analisis di ketahui sebuah sistem hydrolic memiliki 5 gejala kerusakan yang dialami pada sistem hydrolic pada excavator.

[ACG01] = Brake Drum is Not Released

[ACG02] = Hydraulic Pressure is Low

Normally

[ACG03] $=$ Clutch does not Function

[ACG04] = Winch Motor does not Function Normally

[ACG05] = Clutch Pressure is Low

Nilai CF dari masing-masing GEJALA DIATAS diatas adalah dengan mengurangkan nilai antara $\mathrm{MB}$ dengan nilai $\mathrm{MD}$, seperti berikut:

\begin{tabular}{|c|c|c|}
\hline$[\mathrm{CF}[\mathrm{H}, \mathrm{E}] 1][0.8]$ & $-\quad[0.09]$ & $=0.71$ \\
\hline$[\mathrm{CF}[\mathrm{H}, \mathrm{E}] 2][0.7]$ & {$[0.09]$} & $=0.61$ \\
\hline$[\mathrm{CF}[\mathrm{H}, \mathrm{E}] 3][0.5]$ & {$[0.04]$} & $=0.46$ \\
\hline$[\mathrm{CF}[\mathrm{H}, \mathrm{E}] 4][0.4]$ & $-\quad[0.03]$ & $=0.37$ \\
\hline
\end{tabular}

$[\mathrm{CF}[\mathrm{H}, \mathrm{E}] 5][0.4]-[0.04]=0.36$

Maka nilai kombinasi antar $\mathrm{CF}(\mathrm{H}, \mathrm{E})$ adalah:

$\mathrm{CF}[\mathrm{H}, \mathrm{E}] 1.2=\mathrm{CF}[\mathrm{H}, \mathrm{E}] 1+(\mathrm{CF}[\mathrm{H}, \mathrm{E}] 2 *(1-$ $\mathrm{CF}[\mathrm{H}, \mathrm{E}] 1))$

$$
\begin{aligned}
& =0.71+0.61 *(1-0.71) \\
& =0.8869 \rightarrow \text { old } 1
\end{aligned}
$$

$\mathrm{CF}[\mathrm{H}, \mathrm{E}]$ old $1,3=\mathrm{CF}[\mathrm{H}, \mathrm{E}]$ old $1+$ $(\mathrm{CF}[\mathrm{H}, \mathrm{E}] 3 *(1-\mathrm{CF}[\mathrm{H}, \mathrm{E}] \mathrm{old} 1))$

$0.8869)$

$$
=0.8869+0.46 *(1-
$$

$$
\begin{aligned}
& \begin{aligned}
& =0.9389 \rightarrow \text { old } 2 \\
\mathrm{CF}[\mathrm{H}, \mathrm{E}] \mathrm{old} 2,4 & =\mathrm{CF}[\mathrm{H}, \mathrm{E}] \text { old } 2+
\end{aligned} \\
& \mathrm{CF}[\mathrm{H}, \mathrm{E}] 4 *(1-\mathrm{CF}[\mathrm{H}, \mathrm{E}] \mathrm{old} 2)) \\
& =0.9389+0.37 *(1-9389) \\
& =0.9615 \rightarrow \text { old } 3 \\
& \mathrm{CF}[\mathrm{H}, \mathrm{E}] \mathrm{old} 3,5=\mathrm{CF}[\mathrm{H}, \mathrm{E}] \text { old } 3+ \\
& (\mathrm{CF}[\mathrm{H}, \mathrm{E}] 5 *(1-\mathrm{CF}[\mathrm{H}, \mathrm{E}] \mathrm{old} 3)) \\
& =0.9615+0.36 *(1- \\
& =0.9916 \rightarrow \text { old } 3
\end{aligned}
$$

$0.9615)$

bahwa prosentase antara 5 Gejala Kerusakan yang timbul akibat gejala yang dipilih adalah kerusakan Winding Imposible dengan presentase $0.9916 *$ $100 \%=99 \%$. Persentase $=$ CFcombine $* 100=$ $0.9916 * 100=99 \%$

Tahap selanjutnya setelah proses implementasi selesai dikerjakan adalah tahap testing atau pengujian sistem. Use case perancangan aplikasi sistem pakar mendeteksi kerusakan sistem hydrolic pada excavator dengan menggunakan metode $\mathrm{CF}$, Gambar 2. Class Diagram adalah sebuah spesifikasi yang instansi akan menghasilkan sebuah objek dan merupakan inti dari pengembangan dan desain berorientasi objek class menggambarkan keadaan atribut ataupun properti suatu sistem, Gambar 3. 


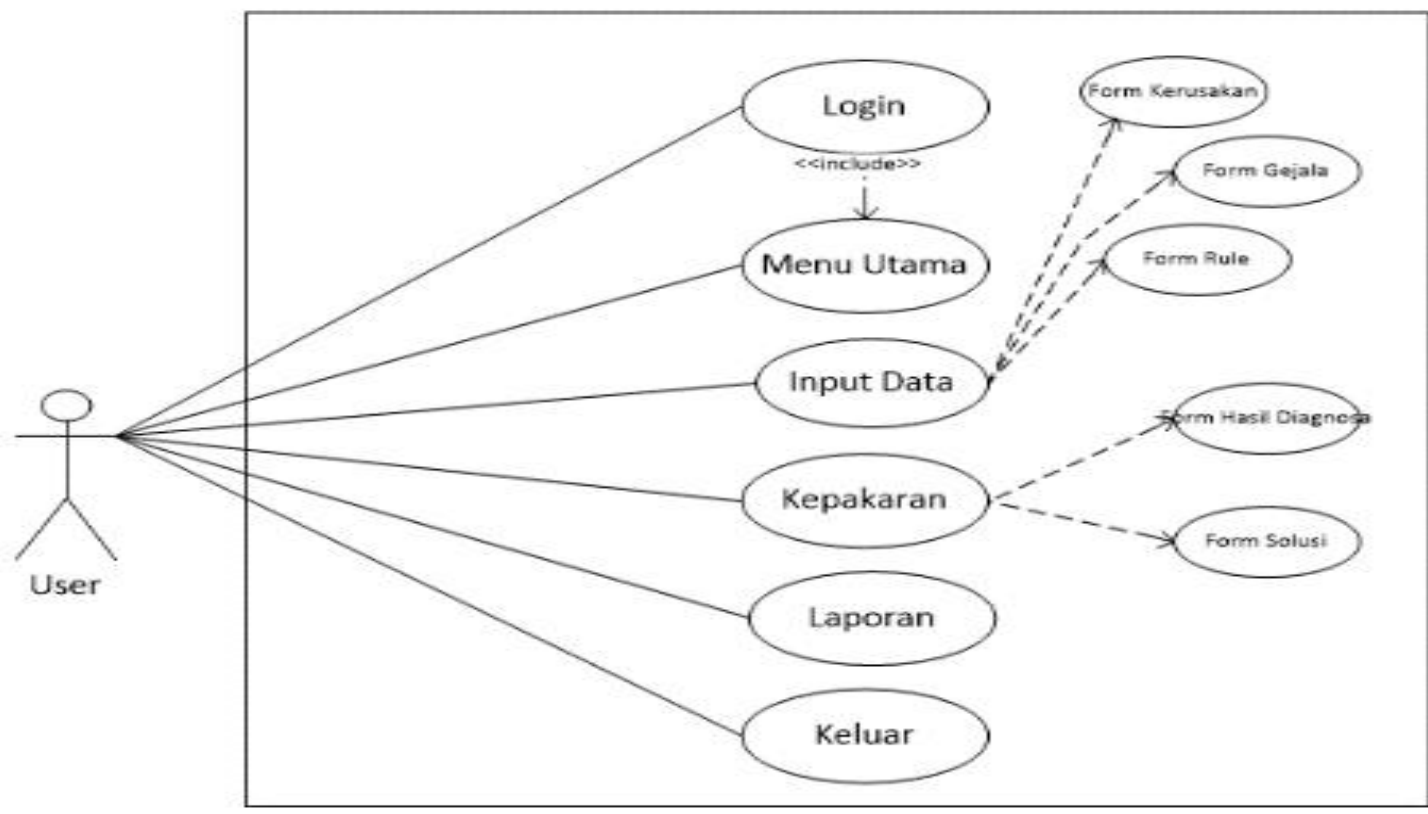

Gambar 2. Use Case Certany Factor

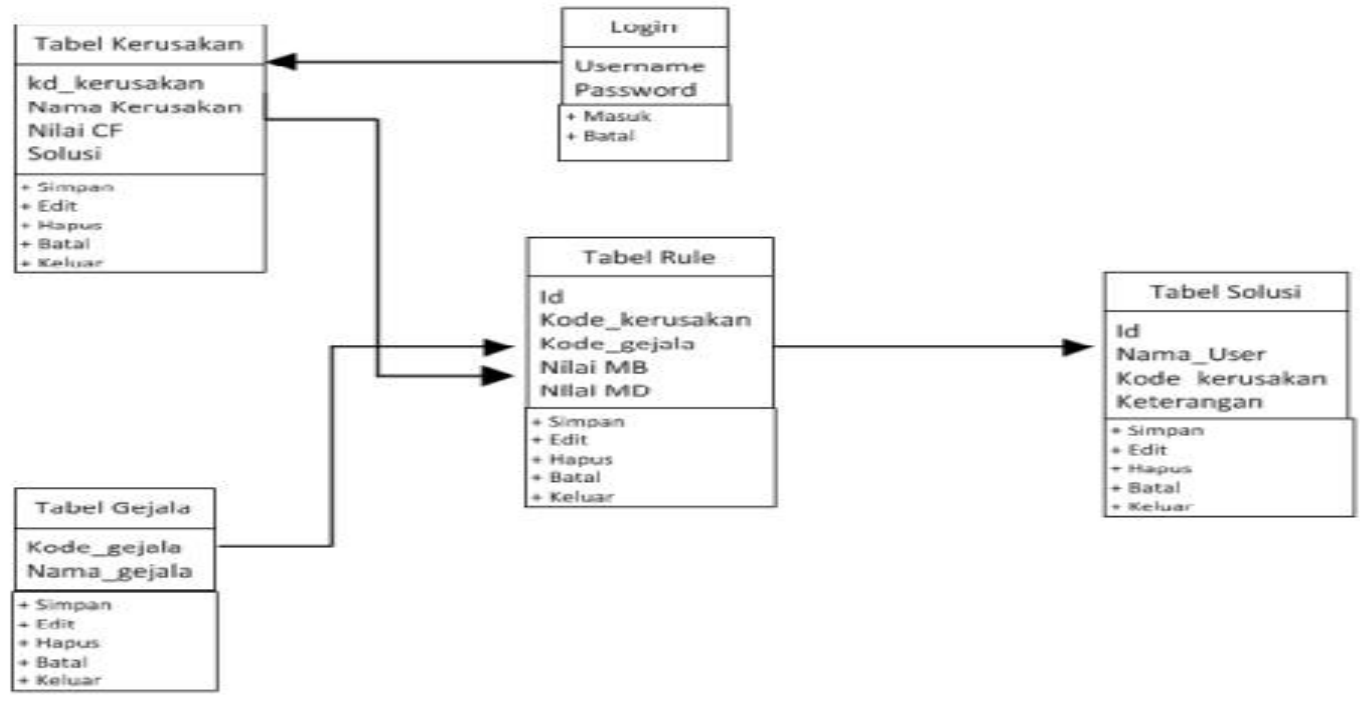

Gambar 3. Class Diagram Certany Factor 
Tahapan Implementasi merupakan tahap dimana aplikasi siap untuk dioperasikan pada keadaan yang sebenarnya sesuai dari hasil analisis dan perancangan yang dilakukan, sehingga akan diketahui apakah sistem atau aplikasi yang dirancang benar-benar dapat menghasilkan tujuan yang dicapai. Aplikasi Sistem Pakar ini dilengkapi dengan user interface yang menarik dan bertujuan untuk memudahkan pengguna dalam menggunakannya.

Pada aplikasi ini memiliki interface atau desain form yang terdiri dari form Login, form menu utama, form kerusakan form gejala, form rule, Form Hasil Diagnosa, dorm Solusi dan form laporan. Form Data kerusakan adalah form yang berfungsi untuk mengelola data kerusakan sistem hydrolic yang ada pada Sistem. Pada form ini, user dapat menginputkan data kerusakan baru atau menghapus serta mengubah data kerusakan.

Form Gejala adalah Form yang digunakan untuk mengelola data Gejala kerusakan pada sistem hydrolic yang ada pada Sistem. Berikut adalah tampilan form Gejala, Gambar 4. Form Rule adalah Form yang digunakan untuk mengelola data hubungan antara Gejala dan kerusakan (rule) pada sistem hydrolic yang ada pada Sistem. Berikut adalah tampilan form Basis Aturan, Gambar 5.

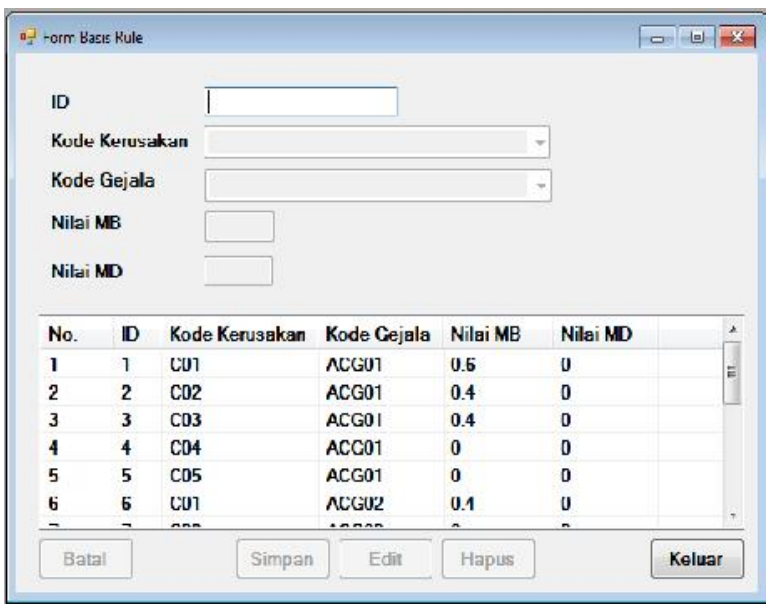

Gambar 4. Tampilan Form Gejala

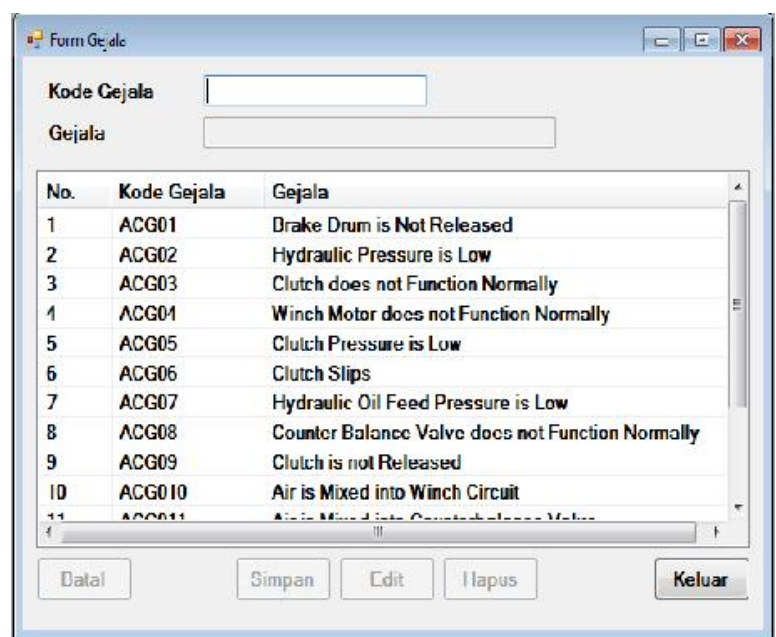

Gambar 5. Tampilan Form Rule

Form Diagnosa adalah form yang akan digunakan oleh user untuk Menghitung gejala yang dipilih dengan menggunakan algoritma Certainty Factor yang nantinya akan menghasilkan hasil diagnosa kerusakan dan penanganannya, Gambar 6.

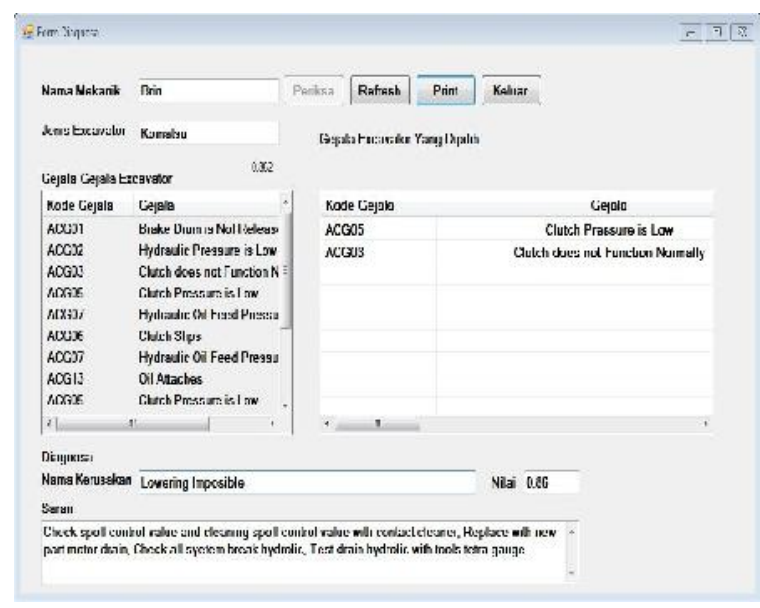

Gambar 6. Tampilan Form Hasil Diagnosa

\section{Kesimpulan}

Kesimpulan dari penelitian :

1. Sistem Pakar dengan Metode Certainty Factor dapat dipergunakan untuk mendiagnosa kerusakan sistem hydrolic dengan menginput data gejala, data kerusakan, Nilai MB, Nilai MD maka output sistem akan menginformasikan jenis kerusakan dan cara mengatasinya. Gejala kerusakan sistem hydrolic pada Excvator yang dibahas dalam sistem pakar ini hanya 14 gejala. Analisa gejala dipengaruhi Nilai MB (tingkat keyakinan), dan Nilai MD (nilai ketidakyakinan).

2. Dari hasil perhitungan nilai $\mathrm{CF}$ dari masingmasing kerusakan, maka akan dipilih nilai $\mathrm{CF}$ yang terbesar. nilai maksimal merupakan hasil dari diagnosa menurut gejala yang diinputkan user. 
3. Aplikasi yang telah dirancang dapat menghitung atau mengolah nilai dari tiap gejala yang dipilih, dapat dengan mudah dimengerti dan digunakan karena rancangan interface yang sederhana dan mempermudah seorang pakar dalam mengetahui jenis kerusakan dengan cepat.

\section{Daftar Pustaka}

[1] Fitri Insani "Penerapan Infrensi Sistem Tsukamoto Pada Klasifikasi Kerusakan Mesin Hydrolic Excavator", Program Studi Teknik Informatika Fakultas Ilmu Komputer Universitas Islam Negeri Riau, 2018.

[2] A Sindar RMS, Sistem Bilangan Digital, Penerbit CV. AA. Rizky Serang Banten 1, 1-78 Oktober 2019.

[3] D. T. Yuwono, A. Fadlil dan Sunardi, "Penerapan Metode Forward Chaining dan Certainty Factor pada Sistem Pakar Diagnosa Hama Anggrek Coelogyne Pandurata," Ilmu Komputer (KLIK), vol. 04, no. 02, pp. 136-145, 2017.

[4] Novi Sri Wanti Ginting, Anita Sindar RMS, Sistem Pakar Diagnosa Penyakit Kacang Kedelai Menggunakan Metode Certainty Factor, UPI YPTK Jurnal KomTekInfo Vol. 5, No. 1, , Hal.36-41. Desember 2018.

[5] Aryu Hanifah Aji, M. Tanzil Furqon, Agus Wahyu Widodo, Sistem Pakar Diagnosa Penyakit Ibu Hamil Menggunakan Metode Certainty Factor (CF), Jurnal Pengembangan Teknologi Informasi dan Ilmu Komputer, Vol. 2, No. 5, , hlm. 2127-2134, Mei 2018.

[6] Roindah Simalango, Anita Sindar Sinaga, Bayes Diagnosa Penyakit Ikan Hias Air Tawar Dengan Teorema Bayes, Journal Publications \& Informatics Engineering Research (SinKron), Volume 3 Nomor 1, Oktober 2018, hal: 43-50.

[7] Khairina Eka Setyaputri, Abdul Fadlil2, dan Sunardi, Analisis Metode Certainty Factor pada Sistem Pakar Diagnosa Penyakit THT, Jurnal Teknik Elektro Vol. 10 No. 1, hal. 30.

[8] Fitri Insani "Penerapan Infrensi Sistem Tsukamoto Pada Klasifikasi Kerusakan Mesin Hydrolic Excavator", Program Studi Teknik Informatika Fakultas Ilmu Komputer Universitas Islam Negeri Riau, 2018.

[9] Haryono Yusman" Sistem Pakar Deteksi Kerusakan Dini Pada Mesin Mobil Toyota Dengan Metode Certainty Factor (CF) Berbasis Web" Program Studi Teknik Informatika Fakultas Teknik Universitas Bengkulu 2017.

[10] Dedi Suryadi” Sistem Pakar Untuk Mengidentifikasi Kerusakan Mesin Industri Menggunakan Metode Certainty Factor" Program Studi Teknik Informatika Fakultas
Teknik Universitas Bengkulu 2018.

[11] Yuliyana, Anita Sindar Ros Maryana Sinaga, Sistem Pakar Diagnosa Penyakit Gigi Menggunakan Metode Naive Bayes, Fountain of Informatics Journal Volume 4, No. 1, Mei 2019 hal. 19-23.

[12] Andri Syahputra, "Sistem Pakar Kerusakan Mesin Jahit Dengan Menggunakan Metode Certainty Factor Berbasis Android”, Program Studi Teknik Informatika STMIK PalCom Tech Palembang, 2016.

[13] D. Suryadi, R. Meilianda, A. Suryono, and M. Munadi, "Sistem Pakar untuk Mengidentifikasi Kerusakan Mesin Industri Menggunakan Metode Certainty Factor," ROTASI, vol. 20, no. 1, pp. 56-62, Jan. 2018.

[14] S. Susmanto, Z. Zulfan, and M. Munawir, "Sistem Penerapan Fuzzy Multi Attribute Decision Making (MADM) Dalam Mendukung Keputusan Untuk Menentukan Lulusan Terbaik Pada Sekolah Tinggi Teknik Poliprofesi Medan," J. Nas. Komputasi dan Teknol. Inf., vol. 1, no. 1, 2018. 